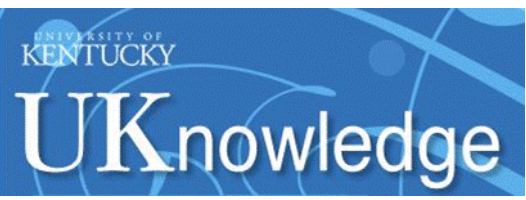

University of Kentucky

UKnowledge

Institute for the Study of Free Enterprise

Working Papers

Institute for the Study of Free Enterprise

6-2017

\title{
The Growth of Government, Trust in Government, and Evidence on Their Coevolution
}

\author{
Steven Gordon \\ University of Kentucky, Steven@SphereQI.com \\ John Garen \\ University of Kentucky, john.garen@uky.edu \\ J. R. Clark \\ University of Tennessee at Chattanooga, j-clark@utc.edu
}

Follow this and additional works at: https://uknowledge.uky.edu/isfe_papers

Part of the Economics Commons

Right click to open a feedback form in a new tab to let us know how this document benefits you.

\section{Repository Citation}

Gordon, Steven; Garen, John; and Clark, J. R., "The Growth of Government, Trust in Government, and Evidence on Their Coevolution" (2017). Institute for the Study of Free Enterprise Working Papers. 20. https://uknowledge.uky.edu/isfe_papers/20

This Research Paper is brought to you for free and open access by the Institute for the Study of Free Enterprise at UKnowledge. It has been accepted for inclusion in Institute for the Study of Free Enterprise Working Papers by an authorized administrator of UKnowledge. For more information, please contact UKnowledge@lsv.uky.edu. 


\title{
The Growth of Government, Trust in Government, and Evidence on Their Coevolution
}

\author{
Steven Gordon \\ John Garen \\ J.R. Clark
}

June 2017

Institute for the Study of Free Enterprise Working Paper 9

University of Kentucky

244 Gatton College of Business and Economics

Lexington, KY 40506-0034 
Gordon, Steven, John Garen, and J. R. Clark. “The Growth of Government, Trust in Government, and Evidence on Their Coevolution.” Schnatter Institute Working Paper. John H. Schnatter Institute for the Study of Free Enterprise, University of Kentucky, Lexington, KY, June 2017.

\begin{abstract}
The coevolution of trust in government alongside the growth of government is an aspect of the latter topic that has not been explored. Moreover, trust is viewed as part of social capital, facilitating social and economic transactions and the governance of society, and its decline has caused concern. We consider this coevolution in the context of a political economy model and a public interest view of government growth, incorporating the role of trust in government. Though a negative association of the growth in government with trust in government is broadly consistent with the historical data since the late 1950s, we present an econometrically sophisticated, time series analysis of the data. We find strong evidence that two aspects of government size - transfer payments and regulatory activity—align with the political economy model where government growth erodes trust. Specifically, we find cointegration indicating the following: negative associations of trust and lobbying activity and of trust and each of these two measures of government, and a positive association of trust and productivity. Though other measures of government size do not produce such robust findings, we do not find evidence of positive associations of trust and government size nor of trust and lobbying, as might be expected from a public interest view of government.
\end{abstract}

Steven Gordon

University of Kentucky

Gatton College of Business and Economics

Department of Economics

Lexington, KY 40506-0034

steven.gordon@uky.edu

J. R. Clark

The University of Tennessee at Chattanooga

313 Fletcher Hall, Dept. 6106

615 McCallie Avenue

Chattanooga, TN 37403-2598

J-Clark@utc.edu

Keywords: trust, government growth
John Garen

University of Kentucky

Gatton College of Business and Economics

Department of Economics

Lexington, KY 40506-0034

jgaren@uky.edu

Schnatter Institute Working Papers are circulated for discussion and comment purposes. They have not been peer reviewed through the institute. Working Papers present an author's provisional findings, which, upon further revision, are likely to be republished in an academic journal. The opinions expressed in Schnatter Institute Working Papers reflect the views of the authors and may not represent the opinions of the Schnatter Institute or the University of Kentucky. 


\title{
The Growth of Government, Trust in Government, and Evidence on Their Coevolution
}

\author{
Steven Gordon, John Garen, J.R. Clark ${ }^{1}$
}

\section{Introduction}

The growth in government in the United States and other parts of the world has been extensively researched. Much of this research aims to understand this expansion, but scholars in economics, political science, and legal studies are often divided regarding the role of government, and its growth, in economic life. Two contrasting models, the public interest and political economy views of government, present simple characterizations of this divide and have different implications for social well-being and economic production as a result of increases in government activity (Mueller 2004).

Another trend in the United States over the past 60 years that has gained attention is the decline of public trust in government (Pew Research Center 2010). This decline has caused great unease among many commentators, with the concern that trust is an important aspect of social capital and its weakening may detract from the efficacy of government, as well as ease of economic and social interactions. ${ }^{2}$ Social capital encompasses the implicit "rules" of a society that affect social governance in many ways and perhaps are just as important as written, legal rules.

\footnotetext{
${ }^{1}$ For comments and suggestions, we thank Joshua Hall, Dwight Lee, Ana Herrera, James Fackler, and session participants at the Southern Economic Association meetings and the Association of Private Enterprise Education conference. For support, we thank the Probasco Chair of Free Enterprise at The University of Tennessee at Chattanooga, the Schnatter Institute for the Study of Free Enterprise, and the BB\&T Program for the Study of Capitalism, both of the latter two at the University of Kentucky.

${ }^{2}$ As examples, see Nye, Zelikow, and King (1997); Hunter and Bowman (1996); Warren (1999); Dalton (2004); Blind (2006); Hetherington (2005); Pharr and Putnam (2000); Lewis (2010); Berggren, Bjornskov, and Lipka (2015); and Berggren and Bjornskov (forthcoming).
} 
This paper presents an empirical examination that relates these two phenomena, that is, the mutual evolution of the growth of government on one hand, and the decline in trust of government on the other. Additionally, our findings speak to whether the public interest or political economy model is a more compelling viewpoint from which to understand the coevolution of these trends. They also address whether the growth of government has tended to erode or enhance the trust aspect of social capital. As discussed below, the political economy model implies a long-run outcome where growth in government erodes trust in government, thus growth in the former is associated with a decline in the latter. The public interest model suggests a positive long-run relationship of trust and government growth. Though the raw correlations are indicative of the political economy model, our empirical work looks for robust, long-run associations in the data regarding the size of government, trust in government, and other variables. Because we use time-series data that may be non-stationary, caution must be taken in the interpretation of correlations, and we are careful to utilize the appropriate time series methods.

While our analysis is based on the microeconomics of rent-seeking as well as on the literature on trust, reciprocity, and social capital, we examine neither the details of particular economic or political markets nor the ebb-and-flow of historical events. Indeed, our approach abstracts from this level of detail and focuses on economy-wide trends of and associations among four variables: the size of government, trust in government, lobbying/rent-seeking activity, and labor productivity. We test whether these variables maintain long-run associations with one another, that is, if they are cointegrated, and whether the findings are consistent with either of the above viewpoints. Thus, the paper presents a novel approach that is relevant to the political economy literature, studies of the growth of government, and work on trust, social 
capital, and social governance. Moreover, it provides new empirical evidence with which to interpret major economic and social trends.

The remainder of the paper is organized as follows: Section II presents an overview of the literature of the growth of government, with discussion of central themes that are closely tied to the political economy and public interest models. Section III presents the theoretical discussion and empirical implications of the political economy model as well as the implications of the public interest view. The role of social capital and trust in government is discussed and incorporated here. Section IV provides an overview of the data. Section V describes the econometric analysis and the findings. We specify an empirical model that allows us to examine the long-run association of, and the dynamics of the relationship between, government size and trust in government. Using the vector error correction model (VECM), we test for and characterize the long-run (cointegrating) relationship between trust, government size, and two other variables that we hypothesize play a role in the dynamic adjustment process: lobbying/rentseeking and labor productivity. When measuring government activity with federal transfer spending or with pages in the Code of Federal Regulations, our estimates imply the existence of a long-run association between trust and government size where higher levels of government lead to lower trust, greater lobbying/rent-seeking, and lower productivity. This is consistent with the political economy model. Results using other measures of government size do not support the political economy model, though there is no support for the public interest framework. Section VI concludes. 


\section{The Growth of Government: A Brief Discussion}

This section provides a short discussion of the literature on the growth of government, since it is one of the phenomena of interest. A good deal of this literature speaks to the above-noted models of government growth.

In this literature, a worthwhile distinction is made between political and non-political factors, to use the terms of Holsey and Borcherding (1997); similar terminologies are institutional and a-institutional factors, used by Borcherding and Lee (2004). ${ }^{3}$ Non-political (ainstitutional) factors include the price and income elasticities of demand for public services and the cost of providing public services. Baumol (1967) argued that the cost of government services is likely to rise over time and this, in conjunction with a low price elasticity for government services, may lead to a growth in government. These ideas are supported by empirical work, and it is well accepted that they have contributed to the growth of the public sector (e.g., Lybeck and Henrekson 1988; Ferris and West 1993). ${ }^{4}$ Wagner's Law (Wagner 1893), which contends that government services grow faster that a society’s wealth, suggests a high income elasticity for government. However, extant empirical work finds a low income elasticity (e.g., Ram 1987; Gemmell 1990; Henrekson 1990), thus failing to explain the growth of government. Note that these non-political explanations refer to individuals’ willingness-to-pay for government services and to the cost of providing them. This suggests efficiency-based reasons for the growth of government, in keeping with a public interest explanation. As discussed below, public-interest driven growth of government is expected to foster trust, social capital and implicit social governance.

\footnotetext{
${ }^{3}$ For more complete discussions of the literature and a full set of references, we refer the reader to Holsey and Borcherding (1997) and Borcherding and Lee (2004), as well as to Kau and Rubin (2002).

${ }^{4}$ Spann (1977) and Ferris and West (1999) find that the price of government services has risen over time, and many studies find a low price elasticity for government services; e.g., Perkins (1977) and Gramlich (1985).
} 
Political (or institutional) reasons for the growth of government focus on political institutions that may enable rent-seeking and the influence of interest groups in gaining redistribution. Naturally, this is a reflection of the political economy viewpoint. Perhaps the most fundamental of these factors is the median voter model. See, for example, Stigler (1970) and the supporting empirical work of Meltzer and Richard (1983). Peltzman (1980) examines incomebased rent-seeking coalitions, emphasizing both between-group inequality and within-group equality. Related studies in this vein link the growth of government to expansions of voter eligibility and changes in electoral rules that may lead to more redistribution. ${ }^{5}$ Still others emphasize the number and size of interest groups, as well as the transaction costs of their formation (Demsetz 1982; Becker 1983); the role of government bureaucrats (Niskanen 1971); and Leviathan models (Brennan and Buchanan 1977). Below, we discuss how interest-group driven growth of government is expected to erode trust and social capital.

A related approach is that of Kau and Rubin (2002), who classify reasons for the growth of government that stem from citizen/interest group desire for government spending as demand factors. These include both the political and non-political factors noted above, but also the role of ideology. ${ }^{6}$ They also examine factors that deal with the ease of government tax revenue collection and its associated dead-weight costs.

Our paper contributes to this literature by incorporating the role of trust in government into the empirical analysis, a connection that heretofore has not been carefully examined in the data. Below, we describe the relationship of trust in government to growth of government, with factors noted above operating in the background.

\footnotetext{
${ }^{5}$ For example, Husted and Kenny (1997) examine the elimination of poll taxes, Lott and Kenny (1998) investigate the effects of women's suffrage, and Tarabar and Hall (2015) explore the effect of the Seventeenth Amendment. ${ }^{6}$ See their paper for a thorough discussion of the literature on the effect of ideology on voting.
} 


\section{Government and Trust: Theoretical Considerations and Empirical Implications}

\section{The Political Economy Approach}

An important genesis of this work is recognition of the large decline in trust of government over the past several decades. Pew Research Center (2010) reports that respondents who indicate that they trust government "most of the time” or “just about always” fell from 76.6 percent in 1966 to 21.5 percent in $2010 .^{7}$ This decline in trust of government has been cause for concern among many commentators, since trust is an important aspect of social capital. Its decline may reduce the efficacy of government, as well as the efficacy of economic and social interactions, and may erode the implicit rules of social governance. ${ }^{8}$ Notably, this decline in trust occurred during a period of substantial government growth in the United States, largely in the form of federal transfer programs and regulatory activity. This presents something of a paradox: How does a mistrusted institution grow so large? Garen and Clark (2015) synthesize a good deal of the political economy/rent-seeking literature with trust and social capital literature to understand the simultaneous growth in the size and influence of government on one hand, and the decline in trust of government on the other. In this paper, we summarize their synthesis and draw out a fuller set of empirical implications. ${ }^{9}$

The empirical structure to characterize and test is as follows: As a first step, consider the resource allocation decision for individuals and organizations between devoting time/resources toward lobbying/rent-seeking activity or toward productive activity. The amounts allocated

\footnotetext{
${ }^{7}$ Many more details are in Pew Research Center (2010). For other discussions of trends in measures of trust in government for the United States, see Nye, Zelikow, and King (1997) and Hunter and Bowman (1996).

${ }^{8}$ See the work cited in footote $1 .<<<$ Footnote 1 contains acknowledgements. Footnote 2 cites work. To refer readers to previously cited work, CMS recommends, but does not require, including an author citation. $>>>$

${ }^{9}$ The appendix reviews the essential structure of the Garen and Clark (2015) synthesis. Note that they draw upon large and diverse sets of literature on trust, reciprocity, and cooperation; on social capital and productivity; and on rent-seeking and political economy/public choice. Each is discussed in their paper.
} 
depend on the private returns to each. Government may provide opportunities for gaining higher returns to lobbying by, for example, offering favorable regulation or tax breaks/subsidies. Naturally, these opportunities induce more lobbying. Conversely, greater returns to productive activity induce less lobbying and more productive effort. Denote the forces that determine the power of government to induce lobbying by the term $\Omega_{1}$. A linear approximation of these relationships is expressed in the following way:

$$
\mathrm{S}=\mathrm{a}_{1}+\mathrm{b}_{1} \mathrm{P}+\mathrm{c}_{1} \Omega_{1}+\mathrm{d}_{1} \Omega_{2}
$$

where:

$\mathrm{S}=$ the amount of lobbying/rent-seeking activity;

$\mathrm{P}=$ private sector productivity;

$\Omega_{1}=$ exogenous factors that enable government to raise the return to lobbying;

$\Omega_{2}=$ any other exogenous factors that induce more lobbying.

The above discussion entails that $b_{1}<0$ and $c_{1}>0$. That is, higher returns to productive activity reduce S and greater returns to lobbying increase S. We allow for other exogenous influences that affect lobbying, denoted by $\Omega_{2}$, and scale $\Omega_{2}$ so that $\mathrm{d}_{1}>0$.

In the empirical work we report below, we utilize a proxy measure of economy-wide lobbying activity as well as standard economic productivity measures. The factors $\Omega_{1}$ and $\Omega_{2}$ may be observed or unobserved by the analyst, and we do not attempt to measure them. Note that these factors encompass the host of political/institutional reasons discussed above that affect the desire for lobbying (e.g., income distribution, cost of group organization), as well as the power of government to generate revenue and to grant favors to interest groups.

Government spending, or other activity associated with lobbying/rent-seeking, is a product of two factors: the amount of lobbying that occurs and the return to lobbying established 
by politicians. For example, the amount of government spending on a special interest subsidy depends on the level of subsidization that is available and the amount of lobbying done to gain the subsidy. Similarly, the degree of regulation that might protect an interest group depends on the availability (from politicians) of such regulation and the extent of lobbying to obtain it.

Thus, it follows that anything that causes government to increase the return to lobbying, and anything that otherwise increases lobbying, has a positive effect on the amount of government activity devoted to lobbying/rent-seeking. Denote this amount as R. Below, we utilize various empirical proxies for this variable that involve measuring aspects of federal government spending and regulation. A linear approximation to the above associations is:

$$
\mathrm{R}=\mathrm{a}_{2}+\mathrm{b}_{2} \mathrm{P}+\mathrm{c}_{2} \Omega_{1}+\mathrm{d}_{2} \Omega_{2}
$$

where $\mathrm{b}_{2}<0, \mathrm{c}_{2}>0$, and $\mathrm{d}_{2}>0$.

Now consider bringing trust into the framework. Trust and cooperation are linked to ideas of social capital (i.e., customs, norms, and habits) that assist in social cooperation. ${ }^{10}$ Studies have shown the importance of social capital to an economy. ${ }^{11}$ Indeed, recent evidence suggests that trust plays an important role in enabling economic reform (Berggren, Bjornskov, and Lipka 2015; Berggren and Bjornskov forthcoming). Regarding trust in government, a variety of reasons are given for its importance. These mostly have to do with cooperation and involvement in the political process and civic activities, such as jury service, voting, and willingness to work for the government. In other words, cooperation of the above type helps government run more effectively.

Also note that government activity may establish and enforce property rights and other personal rights, maintain contract law, promote competition, deal with public goods, and mitigate

\footnotetext{
${ }^{10}$ A succinct summary is Fukuyama (2000).

${ }^{11}$ See Knack and Keefer (1997) as an example.
} 
externalities. These serve to raise productivity. Trust in and cooperation with government enable and augment the productivity-enhancing effects of these government functions. For example, voluntarily compliance with the known parameters of contract and property law limits disputes and saves on transactions costs. Likewise, cooperation with police investigations makes it easier to enforce laws and improves property rights. Such cooperative attitudes enable government to work more effectively, and this raises private-sector productivity.

In this context, trust in and cooperation with government is much like a public good, with the former raising aggregate social productivity. Thus, one might expect the consequent freerider problem, so it is natural to ask how cooperative attitudes arise in this setting. A great deal of work has been done in experimental labs trying to understand issues of trust, reciprocity, and cooperation. Varied laboratory experiments have repeatedly verified that people engage in reciprocating behavior — trusting and cooperating or withdrawing trust and punishing — even in one-shot prisoners' dilemma games where the dominant strategy is to neither cooperate nor punish. Such findings strongly suggest that behavior is in part determined by perceived fairness, that is, "fair” behavior by the other party is rewarded and "unfair” actions are punished. ${ }^{12}$ Additionally, trust and cooperation are intertwined, with greater trust inducing more cooperation. Furthermore, there is evidence that individuals apply a related standard to cooperation with institutions. For example, Levi, Tyler, and Sacks (2008) find that compliance with the law is dependent on whether the state is viewed as an appropriate authority entitled to be obeyed. Nadler (2005) shows that the perceived illegitimacy of and noncompliance with one law reduces the willingness to comply with law in general. Other research obtains similar results regarding compliance with or trust in government. Various studies find that non-cooperative attitudes toward

\footnotetext{
${ }^{12}$ Fehr and Gachter (2000) provide a succinct summary of these experimental results. See also Henrich, et. al. (2001) and Hayashi et. al. (1999).
} 
government are engendered by perceived inefficiency of government, heavy influence of special interests, misconduct by government officials, and perception of poor macroeconomic policy. ${ }^{13}$ Overall, these findings link to the ideas of reciprocity and cooperation as social norms and suggest that these norms are applied to government. If government is perceived to be effective, this perception is reciprocated with trust and with cooperation. If it is not, trust and cooperation are withdrawn.

These findings regarding trust and productivity are summarized by the following firstorder approximations. Define $\mathrm{T}$ as trust in government. Then:

$$
\mathrm{T}=\mathrm{a}_{3}+\mathrm{b}_{3} \mathrm{R}+\mathrm{c}_{3} \Omega_{3}
$$

where $b_{3}<0$, indicating that an increase in the lobbying/rent-seeking activities of government reduces trust in government. The term $\Omega_{3}$ represents other exogenous factors (observed or unobserved) that increase trust and $\mathrm{c}_{3}>0$ follows from the definition of $\Omega_{3}$.

The final equation, based on the foregoing discussion, involves productivity, P:

$$
\mathrm{P}=\mathrm{a}_{4}+\mathrm{b}_{4} \mathrm{~T}+\mathrm{c}_{4} \mathrm{R}+\mathrm{d}_{4} \Omega_{4}
$$

The coefficient $b_{4}>0$ follows from the idea that the social capital associated with trust in government raises productivity. The coefficient $\mathrm{c}_{4}<0$ is based on standard arguments that aggregate rent-seeking/lobbying activity, R, reduces aggregate productivity. The term $\Omega_{4}$ represents other factors (observed or unobserved) that raise productivity, with $\mathrm{d}_{4}>0$.

Equations (1) through (4) represent the structure of the model that is, the economic causes and effects among the variables of interest $\mathrm{S}, \mathrm{R}, \mathrm{T}$, and $\mathrm{P}$. These are the endogenous variables that are determined by the simultaneous solution of the system. This solution depends on factors outside the model: $\Omega_{1}, \Omega_{2}, \Omega_{3}$, and $\Omega_{4}$. Now, solve for the endogenous variables in

\footnotetext{
${ }^{13}$ See, for example, Blendon et al. (1997), Pharr (2000), and Alesina and Warcziarg (2000).
} 
terms of these outside exogenous factors. The exhibit below summarizes the effect (positive or negative) of each exogenous variable on the endogenous variables. These are the predictions of the political economy model of government activity.

Exhibit 1. Effects of outside factors on the endogenous variables: Political economy model

\begin{tabular}{|l|c|l|l|c|}
\hline & $\begin{array}{l}\Omega_{1} \text { : exogenous } \\
\text { factors raising } \\
\text { the return to } \\
\text { lobbying }\end{array}$ & $\begin{array}{l}\Omega_{2} \text { : exogenous } \\
\text { factors raising } \\
\text { lobbying }\end{array}$ & $\begin{array}{l}\Omega_{3} \text { : exogenous } \\
\text { factors raising } \\
\text { trust }\end{array}$ & $\begin{array}{l}\Omega_{4} \text { : exogenous } \\
\text { factors raising } \\
\text { productivity }\end{array}$ \\
\hline S: lobbying & positive & positive & negative & negative \\
\hline $\begin{array}{l}\text { R: government activity } \\
\text { supporting lobbying }\end{array}$ & positive & positive & negative & negative \\
\hline T: trust in government & negative & negative & positive & positive \\
\hline P: productivity & negative & negative & positive & positive \\
\hline
\end{tabular}

Notice that, regardless of the source of exogenous shocks, clear patterns emerge regarding how endogenous variables are expected to covary. Lobbying, S, and government support of lobbying, R, always move together. Similarly, trust, T, and productivity, P, always move in the same direction. Finally, $\mathrm{S}$ and $\mathrm{R}$ move in the opposite direction of $\mathrm{T}$ and $\mathrm{P}$. Also notice that the political factors inducing government growth, as well as other influences on productivity and trust, operate in the background through the exogenous variables $\Omega_{1}, \Omega_{2}, \Omega_{3}$, and $\Omega_{4}$. As we describe in more detail below, this framework implies that, in a time series setting, the four endogenous variables are cointegrated. Whatever the source of exogenous shocks to the system, these variables are predicted to move together over time as described. Thus, our approach enables us to abstract from the specifics of individual policies, historical events, and individual economic or political markets, focusing instead on the economy-wide associations of key variables. 


\section{An Alternative Framework}

\section{The Public Interest View}

The main alternative framework we consider is the public interest view, where government consistently acts in the best interests of the citizenry. Here, greater discretion for government is utilized to raise productivity, engender trust in government, and enable lobbying that helps bring forth this type of policy.

Denote these "good” aspects of government as G and let L represent lobbying activity to increase $\mathrm{G}$. Let $\Psi_{1}$ be factors that increase the power of government to allocate resources and/or respond to lobbying requests and $\Psi_{2}$ be other factors that may influence government spending and lobbying. Then the above discussion suggests:

$$
\begin{aligned}
& \mathrm{L}=\mathrm{a}_{5}+\mathrm{b}_{5} \Psi_{1}+\mathrm{c}_{5} \Psi_{2} \\
& \mathrm{G}=\mathrm{a}_{6}+\mathrm{b}_{6} \Psi_{1}+\mathrm{c}_{6} \Psi_{2}
\end{aligned}
$$

where $b_{5}, c_{5}, b_{6}$, and $c_{6}$ are all positive. Notice that the non-political factors discussed in the literature on government growth enter here. Change in the demand for government services is encompassed by the term $\Psi_{2}$, that is, factors that increase $G$ and lobbying for $G$.

The public interest view implies that increases in the power of government generate $G$ that raises trust in government and improves productivity. This is expressed as:

$$
\begin{aligned}
& \mathrm{T}=\mathrm{a}_{7}+\mathrm{b}_{7} \mathrm{G}+\mathrm{c}_{7} \Psi_{3} \\
& \mathrm{P}=\mathrm{a}_{8}+\mathrm{b}_{8} \mathrm{G}+\mathrm{c}_{8} \Psi_{4}
\end{aligned}
$$

where $b_{7}$ and $b_{8}$ are positive, $\Psi_{3}$ and $\Psi_{4}$ are outside factors raising trust and productivity, respectively, and $\mathrm{c}_{7}$ and $\mathrm{c}_{8}$ are positive.

As above, we solve for the endogenous variables in this framework. This leads to the findings summarized in Exhibit 2. We find that shifts in $\Psi_{1}$ and $\Psi_{2}$ alter $L, G, T$, and $P$ so that 
they all move together. If these are the predominant sources of shocks in a time series of data, then L, G, T, and P are cointegrated and each has a positive relationship to the other. If changes in $\Psi_{3}$ and/or $\Psi_{4}$ are the major sources of shocks then no comovement is implied. In this case, each affects only one endogenous variable in the system- $-\mathrm{T}$ and $\mathrm{P}$, respectively—with no effects elsewhere. It is under the former set of shocks that cointegration of lobbying, government activity, trust, and productivity are expected. However, the nature of the cointegration is very different than that of the political economy model.

Exhibit 2. Effects of outside factors on the endogenous variables: Public interest model

\begin{tabular}{|l|c|c|c|c|}
\hline & $\begin{array}{l}\Psi_{1} \text { : exogenous } \\
\text { factors raising } \\
\text { the powers of } \\
\text { government }\end{array}$ & $\begin{array}{l}\Psi_{2}: \\
\text { exogenous } \\
\text { factors raising } \\
\text { lobbying }\end{array}$ & $\begin{array}{l}\Psi_{3}: \\
\text { exogenous } \\
\text { factors raising } \\
\text { trust }\end{array}$ & $\begin{array}{l}\Psi_{4} \text { : exogenous } \\
\text { factors raising } \\
\text { productivity }\end{array}$ \\
\hline L: lobbying & positive & positive & zero & Zero \\
\hline G: government activity & positive & positive & zero & Zero \\
\hline T: trust in government & positive & positive & positive & Zero \\
\hline P: productivity & positive & positive & zero & positive \\
\hline
\end{tabular}

\section{A Simplified Version}

A somewhat different version of the public interest framework is the view that the dominant role of government is to step in to deal with adverse shocks to an economy or society. This is readily expressed as a simpler version of equations (5) through (8). Let $\Phi$ denote factors that negatively shock trust and productivity. Suppose that government acts in response to these shocks by raising $\mathrm{G}$ and that this serves to offset these negative shocks to $\mathrm{T}$ and $\mathrm{P}$. This yields the following relationships:

$$
\begin{aligned}
& \mathrm{G}=\mathrm{a}_{9}+\mathrm{b}_{9} \Phi \\
& \mathrm{T}=\mathrm{a}_{10}+\mathrm{b}_{10} \Phi+\mathrm{c}_{10} \mathrm{G} \\
& \mathrm{P}=\mathrm{a}_{11}+\mathrm{b}_{11} \Phi+\mathrm{c}_{11} \mathrm{G}
\end{aligned}
$$


with $\mathrm{b}_{10}<0$ and $\mathrm{b}_{11}<0$, indicating negative shocks to $\mathrm{T}$ and $\mathrm{P}, \mathrm{c}_{10}>0$ and $\mathrm{c}_{11}>0$, indicating a positive effect of $\mathrm{G}$ on $\mathrm{T}$ and $\mathrm{P}$, and $\mathrm{b}_{9}>0$, signifying that $\mathrm{G}$ rises to offset the shock. (Note that lobbying does not enter this version of the model.)

The solution for the endogenous variables shows no unambiguous associations among them. A shift in $\Phi$ generates clear movements in G, but $\mathrm{T}$ and $\mathrm{P}$ may move up or down in the same or in a different direction from $\mathrm{G}$ and from one another. There is no cointegration implied among these three variables.

Consider an interpretation of this model in terms of the interest group model of equations (1) through (4). A simple modification makes the two frameworks more consistent. Suppose that trust in government depends on the ratio of $\mathrm{R}$ to $\mathrm{G}$, where an increase in the ratio lowers trust and a decrease raises it. This is consistent with trust equation (3) in the interest group model and trust equation (10) in the public interest framework. Likewise, with productivity dependent on the $\mathrm{R}$ to $\mathrm{G}$ ratio, productivity equations (4) and (11) become consistent.

This suggests that we ought to have separate measures of R and G, though this requires determining which aspects of government are "good" and which are "bad.” Instead, our approach is to utilize various measures of government and let the nature of cointegration of government with the other variables inform us of the predominant character of the government activity. If we find cointegration with negative associations of government to trust and to productivity, the interest group model is predominant. If there are positive associations, the public interest framework dominates. Our emphasis on cointegration of the four endogenous variables of interest enables us to focus on just those variables, with the various exogenous factors that affect the growth of government acting in the background. 


\section{Data}

Our goal is to examine the inter-relationships among a host of variables that proxy for the phenomena of interest. We do so to assess how consistent the data are with the above frameworks. This section presents an overview of these variables.

Figure 1. Percent of respondents who trust government "most of the time” or "just about always"

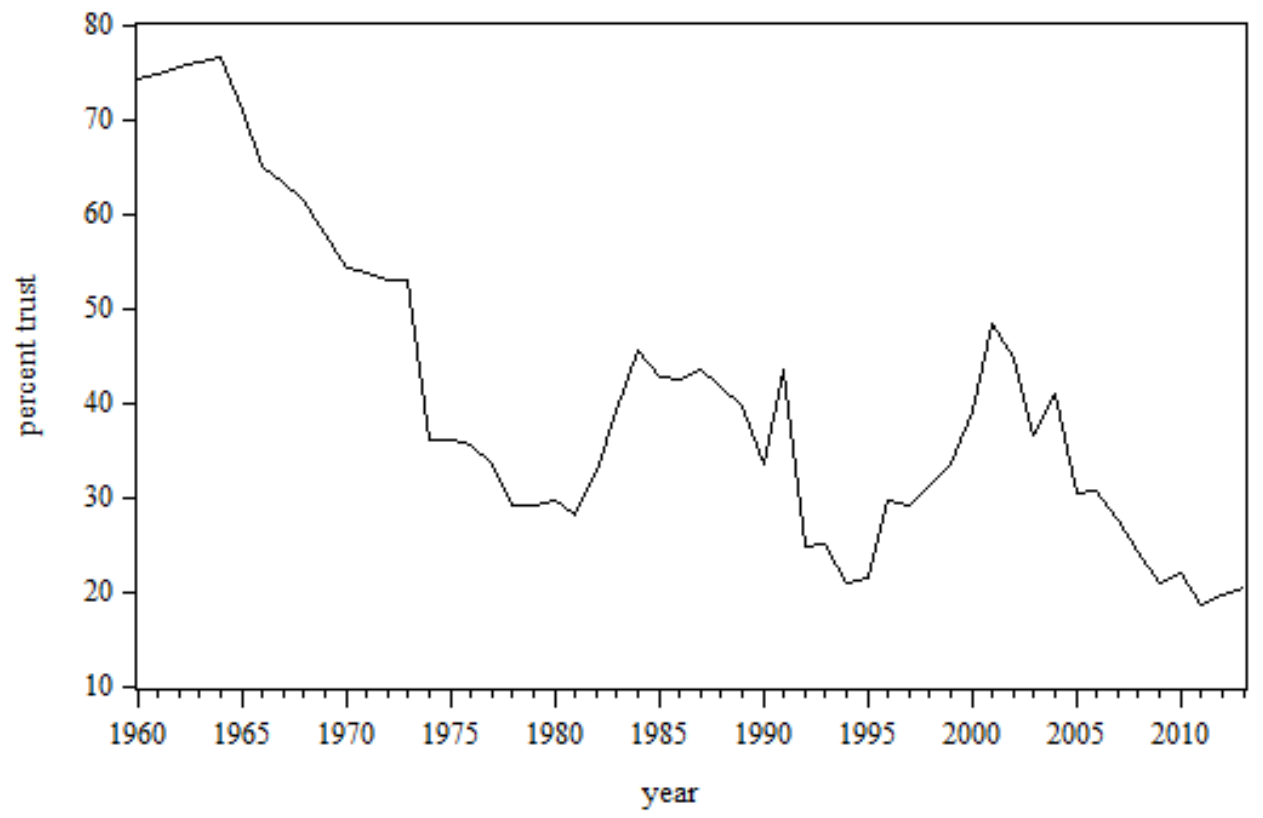

Source: Pew Research Center, http://www.people-press.org/2014/11/13/public-trust-in-government/

Our measure of trust in government is from Pew Research Center data. These data are a compilation of surveys undertaken by several polling organizations and summarized in a standardized fashion. They cover the years 1958 to $2014 .{ }^{14}$ We focus on the percentage of respondents who indicate that they trust government "most of the time” or "just about always.” Figure 1 shows a plot of these data. This measure of trust in government peaked in 1966 at 76.6

\footnotetext{
14 These data are used in Pew Research Center for the People \& the Press (2010) and are summarized at http://www.people-press.org/2014/11/13/public-trust-in-government/. For years that more than one survey was taken, we use the average percent. In some years, no survey of this nature was conducted. In these cases, we enter interpolated data. In the earlier years, such surveys are available for roughly every other year. Since the mid-1970s there is a survey for almost every year.
} 
percent, began to fall markedly, and by 1979 was at 29.0 percent. In subsequent years, the number has ebbed and flowed. Table 1 displays summary statistics for the trust variable, as well as for other variables discussed below.

Table 1. Descriptive statistics

\begin{tabular}{lcccc}
\hline & Mean & Maximum & Minimum & Std. Dev. \\
\hline Trust & 41.30 & 76.60 & 18.60 & 16.61 \\
Political organizations (payrolls) & 45.36 & 73.49 & 31.82 & 11.75 \\
Political organizations & 0.06 & 0.11 & 0.04 & 0.01 \\
Labor productivity & 64.90 & 104.51 & 35.00 & 19.88 \\
Code of Federal Regulations & 91,013 & 155,788 & 37,680 & 36,925 \\
Sum of top 5 regulation titles & 38,893 & 76,618 & 14,311 & 18,389 \\
Transfer payments & 0.07 & 0.11 & 0.04 & 0.02 \\
Federal outlays & 0.19 & 0.24 & 0.16 & 0.02 \\
Federal outlays less defense & 0.14 & 0.20 & 0.08 & 0.03 \\
\hline
\end{tabular}

Notes: All variables in levels. Sample period is from 1960 to 2013 for all variables with the exception of the average marginal tax rate (1960 to 2012). Political organization payrolls as a percentage of total payrolls scaled by a factor of 1 million is a two-year moving average. The labor productivity index has a base year of $2009=100$. Government spending variables (Federal outlays, Federal outlays less defense, and transfer payments) are all as percentages of GDP. Code of Federal Regulations and the sum of the top five titles of the Code of Federal Regulations are raw counts of the number of pages.

Regarding the size of government, we use several measures of government spending, as well as indicators of federal regulation. The spending variables are: federal outlays as a percentage of GDP; total federal outlays less defense spending as a share of GDP; and federal transfer payments as a share of GDP. The total spending measure makes no distinction between the types of federal spending. In subtracting defense spending in the second measure, we are distinguishing defense from non-defense spending. Naturally, the focus of the third measure is transfer spending.

Figure 2 shows the familiar time path of federal outlays as a share of GDP. There was a sizable, albeit somewhat erratic, increase through the 1960s and 1970s, a substantial period of decline through much of the 1980s and 1990s, and a large increase in the 2000s. Figure 3 shows 
the plot for federal transfer payments as a share of GDP. This series is similar to the data on overall federal outlays, but with some exceptions. It shows a fairly steady increase in the 1960s and 1970s, a period in the 1980s and 1990s with little trend, and then a resumption of the upward trend in the 2000s. The correlation between federal transfer spending and total spending is 0.68.

Figure 2. The evolution of federal outlays as a percent of GDP over time

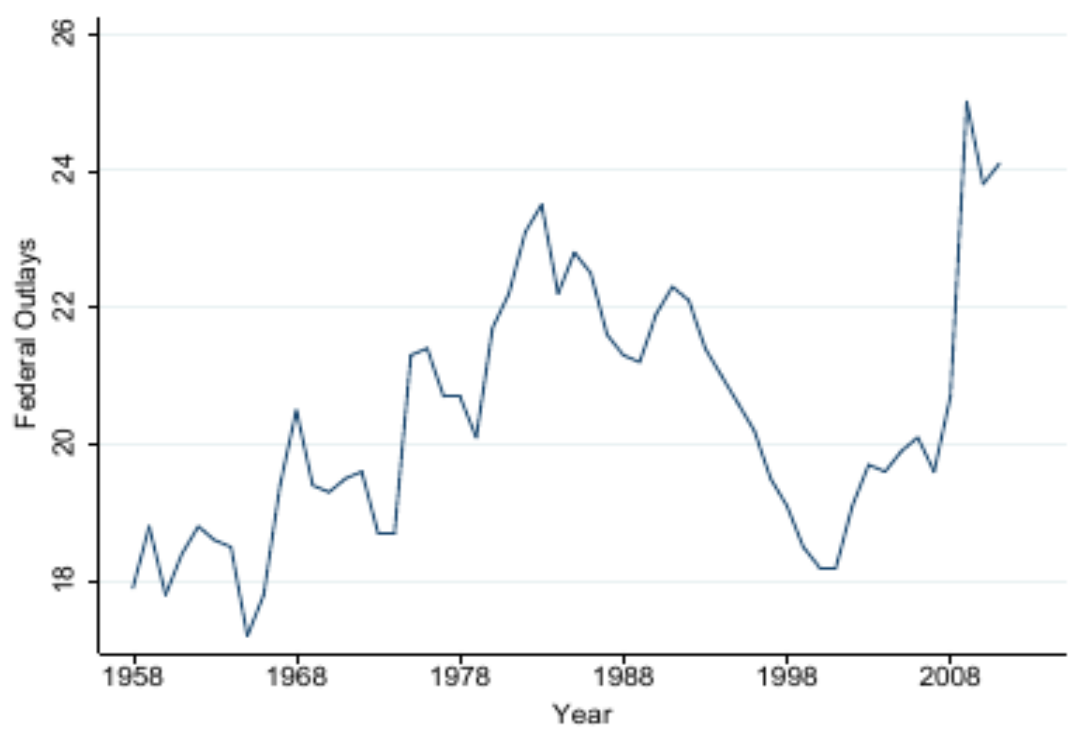

Figure 3. The evolution of transfer payments as a percent of GDP over time

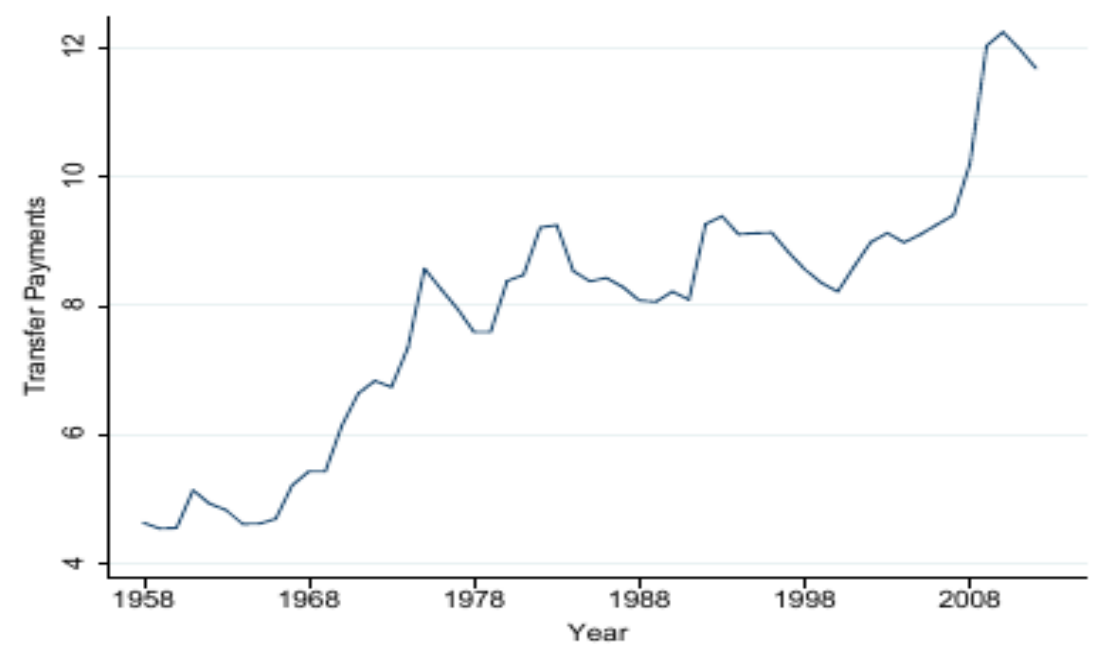


Figure 4. Percent “mistrust” of government and federal outlays/GDP

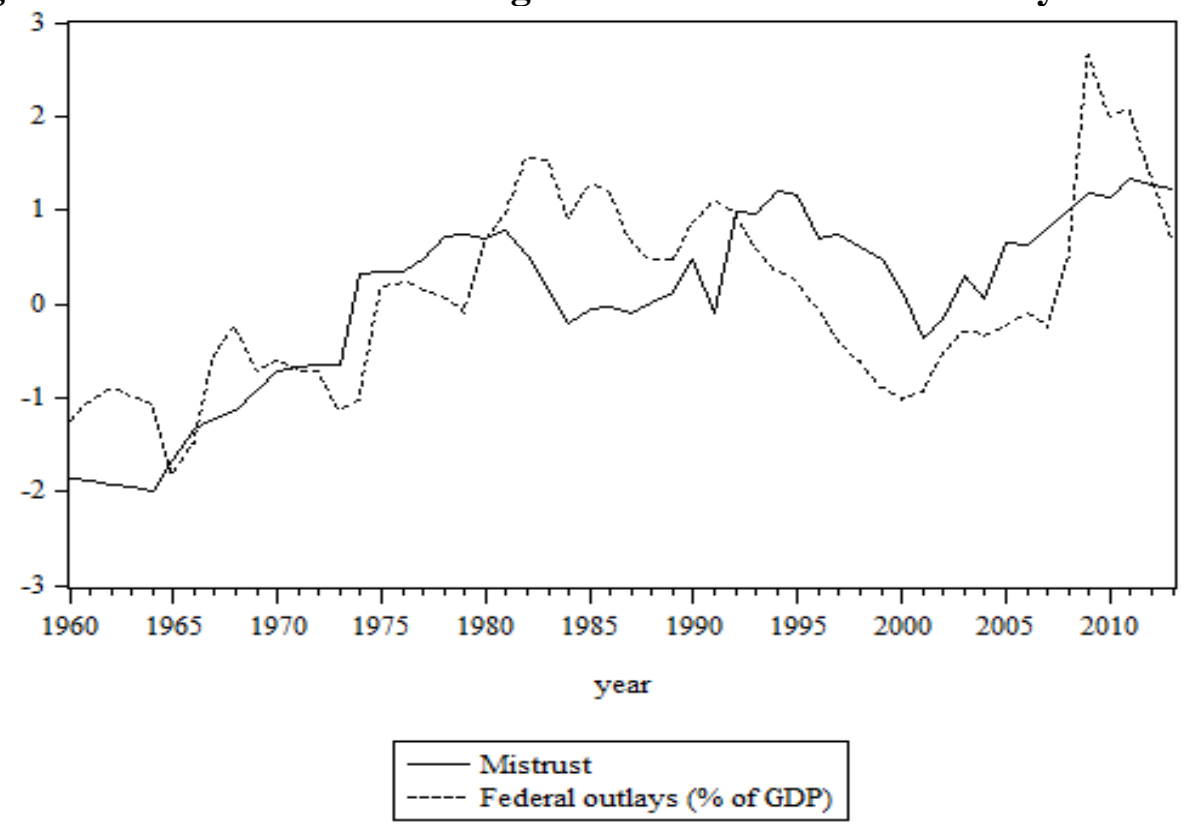

Note: Variables are each normalized to have mean 0 and standard deviation of 1.

Figure 5: Percent “mistrust” of government and federal transfers/GDP

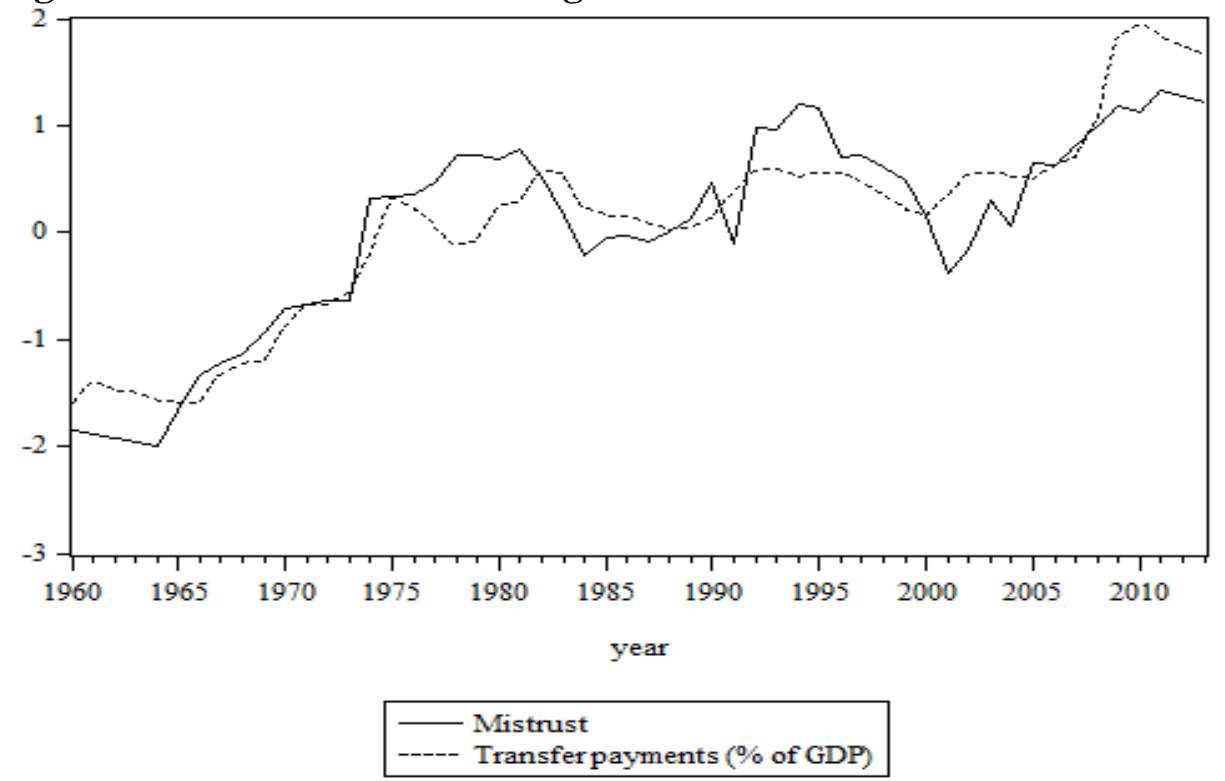

Note: Variables are each normalized to have mean 0 and standard deviation of 1.

To gain a sense of relationships in our data, in figure 4 we plot federal outlays as a share of GDP against the data on trust. For illustrative purposes, we plot “mistrust” instead of "trust." The former is simply 100 percent minus the percent trust measure. Also, to put variables on the 
same scale, we normalize them so each has 0 mean and standard deviation 1 . As can be seen, these two time series move together quite closely. Their correlation coefficient is 0.65 . Figure 5 does a similar plot, but with mistrust against federal transfers as a share of GDP. Visually, these variables track each other very closely. Their correlation coefficient is 0.91 .

To measure federal regulatory activity, we use the number of pages in the Code of Federal Regulations. Dawson and Seater (2013) argue that the Code of Federal Regulations (CFR) is a more precise approximation to the level of regulation than other measures such as pages in the Federal Register. ${ }^{15}$ The page count of total regulations is used to capture both the amount of government regulatory intervention and its complexity, since both more regulations and more complicated regulations should require a greater number of pages. The CFR includes all regulations and is broken into 50 separate titles, with each title covering a different subject area. ${ }^{16}$ We also experiment with using the five titles with the largest number of pages of regulations. These regulatory areas are: environment, wildlife, and fisheries; agriculture; banks and banking; transportation; and labor.

Table 1 also reports summary statistics for the regulation variables. The mean pages in the CFR is over 91,000, varying from a minimum of 37,680 to a maximum of 155,788 . The former value occurred at the beginning of the sample and the latter at the end. Figure 6 plots normalized values of total CFR pages against normalized mistrust. The pattern of CFR pages shows a sizable growth in the 1970s, a slowdown in the early 1980s, a decline in the mid-1990s, and a resumption of growth during the 2000s. Comparing the two time series plots suggests a strong relationship. The correlation of mistrust and CFR pages is 0.80 .

\footnotetext{
${ }^{15}$ However, our data collection shows that the correlation between pages in the Federal Register and the Code of Federal Regulations is very high at 0.89 .

${ }^{16}$ The first six titles of the CFR are excluded because they focus on the internal workings of the federal government.
} 


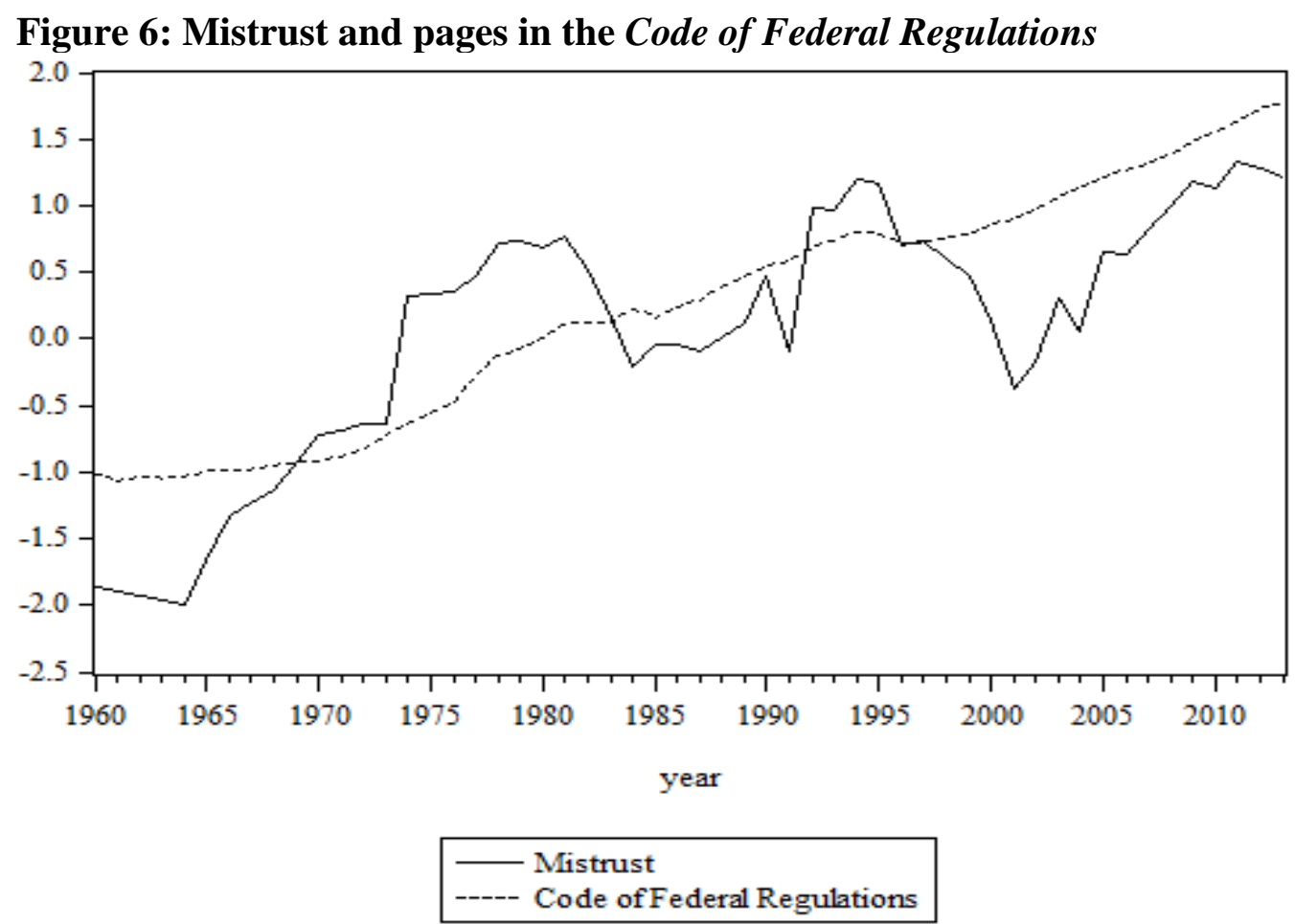

Note: Variables are each normalized to have mean 0 and standard deviation of 1.

As a proxy for rent-seeking activity, we follow Sobel and Garrett (2002) by using data on the lobbying industry. County Business Patterns reports the number of establishments, employment, and total payroll of the industry “political organizations,” which is NAICS industry code 81394 . These data are available each year beginning in $1959 .{ }^{17}$ For our proxy, we use political organizations payrolls as a percentage of total U.S. annual payrolls, scaled by a factor of 1 million. ${ }^{18}$ Additionally, a two-year moving average is used in order to smooth out election year spikes that take place in even years.

We do not claim that our measure captures all the lobbying activity that occurs in the economy. Indeed, much is likely to take place within firms that operate in a multitude of

\footnotetext{
17 The years 1960, 1961, and 1963 were missing and were imputed based on historical trends.

${ }^{18}$ We also experimented with using political organizations employment $<<<$ If possessive, add apostrophe. If not, suggest recast as employment in political organizations $>>>$ as a percentage of total employment. The findings were very similar.
} 
industries. However, we do rely on the assumption that the size of the lobbying industry is closely correlated with the total lobbying activity in the economy. Table 1 shows the summary statistics and figure 7 plots our lobbying measure against mistrust, both normalized. As seen, lobbying rose sharply during the 1980s, slowed in the mid-1990s, rose again in the mid-2000s, then fell again. Mistrust and lobbying tend to move together, though it does not seem as close as with other associations. The correlation coefficient is 0.52 .

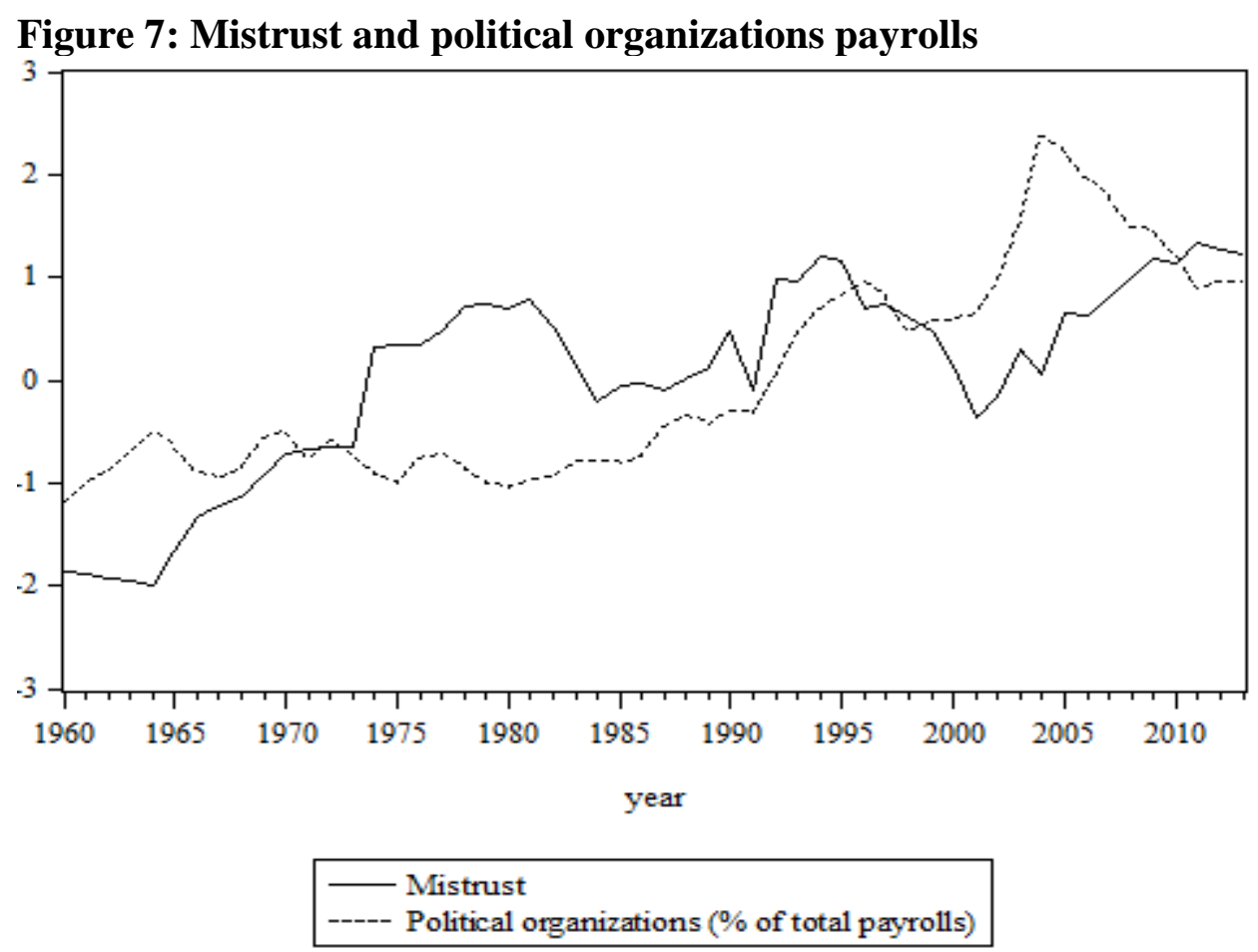

Note: Variables are each normalized to have mean 0 and standard deviation of 1 .

Regarding productivity, we rely on data for labor productivity from the Bureau of Labor Statistics. In particular, we use the non-farm labor productivity index, with a base year of 2009. It is an index of output per hour and its summary statistics are found in table 1. Labor productivity displays a consistently upward trend, though the growth rate does vary. Thus, it would appear to be inversely related to the generally downward-trending trust; indeed, the 
correlation coefficient is -0.73 . However, our multivariate analysis below shows that this is misleading.

Table 2 presents the correlation matrix of variables of interest. Many of the correlations were noted above. Generally, trust has a negative correlation with each of the measures of the size of government, as well as with lobbying. Additionally, lobbying is positively related to the measures of government.

Table 2. Correlation coefficients

\begin{tabular}{lcccccc}
\hline & Trust & Labor & Political & \multicolumn{2}{c}{ Transfer } & \multicolumn{2}{c}{ Fed. outlays Code of Federal } \\
& 1.00 & -0.73 & -0.53 & -0.91 & -0.89 & -0.81 \\
\hline Trust & -0.73 & 1.00 & 0.89 & 0.88 & 0.77 & 0.96 \\
Labor productivity & -0.53 & 0.89 & 1.00 & 0.64 & 0.52 & 0.83 \\
Political organizations & -0.91 & 0.88 & 0.64 & 1.00 & 0.95 & 0.91 \\
Transfer payments & -0.89 & 0.77 & 0.52 & 0.95 & 1.00 & 0.87 \\
Federal outlays less defense & orgs. payroll & payments & less defense & Regulations \\
Code of Federal Regulations & -0.81 & 0.96 & 0.83 & 0.91 & 0.87 & 1.00 \\
\hline
\end{tabular}

Notes: All variables in levels. Transfer payments and federal outlays less defense spending are all as a percentage of GDP.

\section{Econometric Framework and Findings}

\section{Econometric Issues}

Our discussion above focused on understanding the observed empirical associations between trust in government, size of government, lobbying/rent-seeking activity, and productivity. Here, we describe the framework for and results regarding analysis of the variables discussed in the data section.

To investigate these associations, we face the challenge that the variables of interest may be non-stationary. As is well known, spurious correlations among non-stationary variables are more likely to occur than standard statistical inference suggests. All of these series exhibit trends, 
and possibly the presence of non-stationarity. Here, we discuss and apply the appropriate

methods to determine the legitimate associations in our data.

Table 3 displays the results from a battery of tests for non-stationarity (i.e., unit root

tests). All of the series show mixed evidence for the presence of unit roots. However, the power

of these tests tends to be very low and the multiple tests shown provide contradictory evidence

regarding whether many of the series contain unit roots. ${ }^{19}$ Thus, the evidence does not

overwhelmingly support either the acceptance or rejection of unit roots. Because of this, we take

an approach that does not rely on stationary data.

Table 3. Unit root test results

\begin{tabular}{lllllll}
\hline Test & DF-GLS & DF-GLS & KPSS & KPSSit & Perron1 & Perron2 \\
\hline Trust & -0.70 & -2.33 & 0.78 & 0.10 & $<0.01$ & 0.47 \\
Political organizations (payrolls) & -0.60 & -2.48 & 0.74 & 0.16 & 0.70 & 0.73 \\
Political organizations (employment) & -1.61 & -3.47 & 0.86 & 0.12 & 0.01 & 0.52 \\
Labor productivity & 1.24 & -1.51 & 0.92 & 0.12 & 0.95 & 0.57 \\
Code of Federal Regulations & 1.49 & -1.50 & 1.04 & 0.18 & $<0.01$ & 0.44 \\
Sum of top 5 regulation titles & 2.22 & -1.54 & 1.06 & 0.13 & 0.01 & $<0.01$ \\
Transfer payments & 0.52 & -1.61 & 0.81 & 0.19 & 0.61 & 0.68 \\
Federal outlays & -1.31 & -2.18 & 0.47 & 0.13 & 0.50 & 0.56 \\
Federal outlays less defense & -0.33 & -1.50 & 0.69 & 0.20 & 0.42 & 0.68 \\
Average marginal tax rate & -1.77 & -1.89 & 0.20 & 0.17 & $<0.01$ & 0.28 \\
\hline
\end{tabular}

Notes: The DF-GLS and Perron tests both have a null hypothesis of a unit root, while the KPSS test has a null hypothesis of stationarity. Critical values for the DF-GLS assuming level stationarity are -1.61 (10 \%), -1.95 (5 \%), and -2.61 (1\%) respectively, and -2.87 (10\%), -3.17 (5\%), and -3.75 (1\%) assuming trend stationarity. Critical values for the KPSS tests assuming level stationarity are: 0.347 (10 \%), 0.463 (5\%), 0.739 (1\%) and 0.119 (10\%), 0.146 (5 \%), 0.216 (1 \%) for trend stationarity. The Perron1 and Perron2 tests are based on the Perron (1989) unit root testing procedure with possible breakpoints and represent different approaches for the selection of break dates: Perron1 is the test with the selected break that yields the greatest chance of rejecting the null hypothesis of a unit root, while Perron2 represents the test where the most statistically significant break is chosen. Critical values for the Perron1 and Perron2 tests assuming trend stationarity with both trend and intercept breaking are $-4.89(10 \%),-5.18$ (5\%), and -5.92 (1\%), and -4.28 (10\%), -4.62 (5\%), and -3.03 (1\%) respectively. Subscripts "i”" and "t" denote that the test specifications include an intercept or a trend respectively.

This approach is to test for cointegration of the variables of interest: trust in government, size of government, lobbying/rent-seeking activity, and productivity. The political economy

\footnotetext{
${ }^{19}$ We also do some stationarity tests that allow for the presence of breaks.
} 
model implies that these variables always move together in certain ways. Even though each variable may be non-stationary, the relationship among them remains the same. Thus, the variables are expected to be cointegrated with certain associations among them. Similarly, the public interest framework, under certain conditions, implies cointegration but with different associations.

This is expressed in the following way. Let the long-run relationship among these variables be:

$$
\mathrm{T}_{\mathrm{t}}=\mu+\beta_{\mathrm{LP}} \mathrm{LP}_{\mathrm{t}}+\beta_{\mathrm{POL}} \mathrm{POL}_{\mathrm{t}}+\beta_{\mathrm{X}} \mathrm{X}_{\mathrm{t}}+\mathrm{v}_{\mathrm{t}}
$$

where $T_{t}$ is our trust variable, $\mathrm{LP}_{\mathrm{t}}$ is labor productivity, $\mathrm{POL}_{\mathrm{t}}$ is the political organizations payroll variable, $X_{t}$ is the size of government variable, and $v_{t}$ is an error term. If (12) is the true long-run relationship, then $v_{t}$ is stationary and (12) represents the relationship that the series reverts back to in the long run. The $\beta_{\mathrm{j}}$ coefficients define the long-run associations among the four variables. Our political economy model predicts that T and LP move together, POL and X move together, and the first pair move opposite to the second pair. This implies $\beta_{\mathrm{LP}}>0, \beta_{\mathrm{POL}}<$ 0 , and $\beta_{\mathrm{X}}<0$. Note that the cointegrating equation may be normalized to any of the variables and we have normalized trust to have a coefficient of 1 .

Additionally, if cointegration in (12) holds, then error correction should occur. Thus, if $v_{\mathrm{t}}$ $1=\mathrm{T}_{\mathrm{t}-1}-\beta_{\mathrm{LP}} \mathrm{PP}_{\mathrm{t}-1}-\beta_{\mathrm{POL}} \mathrm{POL}_{\mathrm{t}-1}-\beta_{\mathrm{X}} \mathrm{X}_{\mathrm{t}-1}-\mu>0$, trust in period $\mathrm{t}-1$ is higher than expected and should fall in the ensuing period. The opposite holds if $v_{\mathrm{t}-1}<0$. This is expressed in as:

$$
\Delta \mathrm{T}_{\mathrm{t}}=\gamma_{1}+\alpha_{1}\left(\mathrm{~T}_{\mathrm{t}-1}-\beta_{\mathrm{LP}} \mathrm{LP}_{\mathrm{t}-1}-\beta_{\mathrm{POL}} \mathrm{POL}_{\mathrm{t}-1}-\beta_{\mathrm{X}} \mathrm{X}_{\mathrm{t}-1}-\mu\right)+\varepsilon_{1 \mathrm{t}}
$$

where $\alpha_{1}$ is the adjustment coefficient - expected to be negative - and $\varepsilon_{1 \mathrm{t}}$ is white noise. This is a simple version of the error correction model. A full version of this framework is the vector error 
correction model (VECM). This allows for adjustment in all of the variables, controls for lagged changes, and also estimates the cointegrating coefficients simultaneously with the adjustment coefficients.

The full model that we estimate is:

$$
\begin{aligned}
& \Delta \mathrm{T}_{\mathrm{t}}=\gamma_{1}+\alpha_{1}\left(\mathrm{~T}_{\mathrm{t}-1}-\beta_{\mathrm{LPLP}}-1-\beta_{\mathrm{POL}} \mathrm{POL}_{\mathrm{t}-1}-\beta_{\mathrm{X}} \mathrm{X}_{\mathrm{t}-1}-\mu\right)+\Gamma_{1 \mathrm{~T}} \Delta \mathrm{T}_{\mathrm{t}-1}+\Gamma_{1 \mathrm{LP}} \Delta \mathrm{LP}_{\mathrm{t}-1}+ \\
& \Gamma_{1 \mathrm{P}} \Delta \mathrm{POL}_{\mathrm{t}-1}+\Gamma_{1 \mathrm{X}} \Delta \mathrm{X}_{\mathrm{t}-1}+\varepsilon_{1 \mathrm{t}} \\
& \Delta \mathrm{LP}_{\mathrm{t}}=\gamma_{2}+\alpha_{2}\left(\mathrm{~T}_{\mathrm{t}-1}-\beta_{\mathrm{LP}} \mathrm{LP}_{\mathrm{t}-1}-\beta_{\mathrm{POL}} \mathrm{POL}_{\mathrm{t}-1}-\beta_{\mathrm{X}} \mathrm{X}_{\mathrm{t}-1}-\mu\right)+\Gamma_{2 \mathrm{~T}} \Delta \mathrm{T}_{\mathrm{t}-1}+\Gamma_{2 \mathrm{LP}} \Delta \mathrm{LP}_{\mathrm{t}-1}+ \\
& \Gamma_{2 \mathrm{P}} \Delta \mathrm{POL}_{\mathrm{t}-1}+\Gamma_{2 \mathrm{X}} \Delta \mathrm{X}_{\mathrm{t}-1}+\varepsilon_{2 \mathrm{t}} \\
& \Delta \mathrm{POL}_{\mathrm{t}}=\gamma_{3}+\alpha_{3}\left(\mathrm{~T}_{\mathrm{t}-1}-\beta_{\mathrm{LP}} \mathrm{LP}_{\mathrm{t}-1}-\beta_{\mathrm{POL}} \mathrm{POL}_{\mathrm{t}-1}-\beta_{\mathrm{X}} \mathrm{X}_{\mathrm{t}-1}-\mu\right)+\Gamma_{3 \mathrm{~T}} \Delta \mathrm{T}_{\mathrm{t}-1}+\Gamma_{3 \mathrm{LP}} \Delta \mathrm{LP}_{\mathrm{t}-1}+ \\
& \Gamma_{3 \mathrm{P}} \Delta \mathrm{POL}_{\mathrm{t}-1}+\Gamma_{3 \mathrm{X}} \Delta \mathrm{X}_{\mathrm{t}-1}+\varepsilon_{3 \mathrm{t}} \\
& \Delta \mathrm{X}_{\mathrm{t}}=\gamma_{4}+\alpha_{4}\left(\mathrm{~T}_{\mathrm{t}-1}-\beta_{\mathrm{LP} \mathrm{LP}}-\beta_{\mathrm{POL}} \mathrm{POL}_{\mathrm{t}-1}-\beta_{\mathrm{X}} \mathrm{X}_{\mathrm{t}-1}-\mu\right)+\Gamma_{4 \mathrm{~T}} \Delta \mathrm{T}_{\mathrm{t}-1}+\Gamma_{4 \mathrm{LP}} \Delta \mathrm{LP}_{\mathrm{t}-1}+ \\
& \Gamma_{4 \mathrm{P}} \Delta \mathrm{POL}_{\mathrm{t}-1}+\Gamma_{4 \mathrm{X}} \Delta \mathrm{X}_{\mathrm{t}-1}+\varepsilon_{4 \mathrm{t}}
\end{aligned}
$$

\section{Estimation and Results}

Before turning to the final estimation, we test the data for the existence and number of cointegrating relationships, as well as the appropriate lag length in equations (14) through (17). To do so, we follow the procedure of Johansen (1991) to test for the existence of cointegrating relationships among trust, labor productivity, political organizations, and each measure of government activity. The lag length is chosen based on Schwarz's Bayesian information criterion (SBIC), and is found to be one lag for all series. This, and the tests for number of cointegrating relationships, are summarized in table 4 . For each of the measures of government, the null hypothesis of zero cointegrating relationships is rejected, but the null of one cointegrating relationship is not. 
Table 4. Tests for cointegrating relationships

\begin{tabular}{lllc}
\hline Government Variable & \multicolumn{1}{c}{0} & \multicolumn{1}{c}{1} & \multicolumn{1}{c}{2} \\
\hline Transfer payments & 0.0028 & 0.2391 & 0.5388 \\
Federal outlays less defense & 0.069 & 0.5811 & 0.5955 \\
Federal outlays & 0.0301 & 0.31 & 0.5242 \\
Code of Federal Regulations & 0.007 & 0.3125 & 0.3328 \\
Sum of top 5 titles of the & 0.0759 & 0.4834 & 0.5048 \\
Average marginal tax rate & 0.0246 & 0.1019 & 0.1479
\end{tabular}

Notes: Values displayed are from cointegration tests following the Johansen (1991) methodology. Each government variable is included in with the same set of endogenous variables: Trust, labor productivity, and political organizations. Displayed numbers are $p$-values for the trace test statistics. Lag length is chosen based on Schwarz's Bayesian information criterion (SBIC) and is one lag for all series. All tests were specified with a linear trend in the data, and an intercept only in the cointegrating equation.

Table 5. Vector error correction model estimates

\begin{tabular}{|c|c|c|c|}
\hline Parameter & $\mathrm{TP}$ & CFR & FEDDEF \\
\hline \multicolumn{4}{|c|}{ Panel A: Cointegrating coefficients } \\
\hline$\beta \mathrm{T}$ & 1 & 1 & 1 \\
\hline$\gamma 1$ & -3.48 & -16.22 & -4.86 \\
\hline$\beta \mathrm{LP}$ & $\begin{array}{l}-0.59 \\
{[-1.165]}\end{array}$ & $\begin{array}{l}-2.92 \\
{[-2.590]}\end{array}$ & $\begin{array}{l}-0.73 \\
{[-1.105]}\end{array}$ \\
\hline$\beta P O L$ & $\begin{array}{l}1.1 \\
{[2.924]}\end{array}$ & $\begin{array}{l}3.46 \\
{[5.044]}\end{array}$ & $\begin{array}{l}1.51 \\
{[2.735]}\end{array}$ \\
\hline$\beta X$ & $\begin{array}{l}0.71 \\
{[2.395]}\end{array}$ & $\begin{array}{l}1.02 \\
{[1.917]}\end{array}$ & $\begin{array}{l}0.74 \\
{[1.540]}\end{array}$ \\
\hline
\end{tabular}

Panel B: Adjustment coefficient for trust

\begin{tabular}{llll}
\hline$\alpha 1$ & -0.25 & -0.12 & -0.18 \\
& {$[-2.471]$} & {$[-2.361]$} & {$[-2.091]$} \\
\hline
\end{tabular}

Notes: Measure of government activity, $\mathrm{X}=\mathrm{TP}, \mathrm{CFR}$, or FEDDEF. All variables in log levels. T- statistics in brackets. Panel $\mathrm{B}$ includes only the equation for $\Delta \mathrm{T}$ as the dependent variable. $\mathrm{TP}=$ Transfer payments/GDP, $\mathrm{CFR}=$ Code of Federal Regulations, FEDDEF = Federal outlays less defense spending/GDP. Each specification also includes lagged changes of: the measure of government activity $\left(\Delta \mathrm{X}_{\mathrm{t}-1}\right)$, Trust $\left(\Delta \mathrm{T}_{\mathrm{t}-1}\right)$, Labor productivity $(\Delta \mathrm{LP} t-1)$, and Lobbying $\left(\Delta \mathrm{POL}_{\mathrm{t}-1}\right)$.

Table 5 presents the main findings. Note that we use the logarithm for each variable for all specifications. For estimation, the cointegrating equation is expressed as $T_{t}-\mu-\beta_{L P} L P_{t}-$ $\beta_{\text {POL POL }}-\beta_{\mathrm{X}} \mathrm{X}_{\mathrm{t}}-\mathrm{v}_{\mathrm{t}}=0$. Thus, the signs of the estimated parameters are opposite their associations with trust. 
Panel A presents cointegrating coefficients. In the first column, government is measured as TP; transfer payments relative to GDP. The sign pattern is as the political economy model predicts: Labor productivity is positively associated with trust, and the political organizations variable and transfer payments are negatively associated with trust. The latter two show strong statistical significance, while the first does not. In panel B, the error correction coefficient is reported from the trust adjustment equation $\left(\alpha_{1}\right)$. This coefficient is negative and significant as expected. This finding implies that a lagged level of trust higher than the long-run relationship produces a reduction in trust and produces the converse for a lagged level below the long-run association. The coefficients in the other change equations were mostly statistically insignificant and so are not reported here.

The second column displays analogous results, measuring government activity using the number of pages in the CFR. The sign pattern of the cointegrating coefficients is the same as above: Trust and productivity are positively related, and political organizations and government size are negatively related to trust. The coefficients on productivity and political organizations are highly significant, while that on the CFR has a p-value of about 6 percent. Additionally, the estimated adjustment coefficient for trust adjustment shown in panel B is negative and significant.

The last column of table 5 shows the findings for another measure of the size of government: federal outlays less defense spending as a share of GDP. The cointegrating coefficients in panel A show that the sign pattern remains the same, indicating that trust and productivity move together and in the opposite direction of lobbying and government size. In this specification, however, statistical significance is weaker, with only the lobbying variable 
attaining a high level of significance. The adjustment coefficient for trust in panel B has a negative sign and is statistically significant, similar to the above findings.

We also experimented with other measures of the size of government: total federal spending as a share of GDP and pages of the CFR for the highest five areas. For the cointegrating coefficients, the results are somewhat varied, though usually with sign patterns similar to those in table 5, but often without statistical significance. However, regardless of our measure of government, we find little evidence that trust, government size, lobbying, and productivity move together as the public interest model predicts.

Our findings imply that transfers payments as a share of GDP and pages in the CFR behave as though they represent rent-seeking related government activities, in that the cointegrating and adjustment relationships are as predicted by the political economy model. We do not find such robust relationships for other measures of government, though none behave as expected by a public interest view of government.

\section{Conclusion}

The coevolution of trust in government alongside the growth of government is an aspect of the latter topic that has not been explored. Our study examines it from a broad, economy-wide perspective. We find strong evidence that two aspects of government size - transfer payments and regulatory activity—exhibit persistent long-run association with trust in government as well as with other relevant variables. Specifically, we find cointegration indicating the following: a negative association between trust and lobbying activity, a negative relationship between trust and each of these two measures of government, and a positive association between trust and productivity. Various other measures of government size do not produce such robust findings. 
The former findings align with the political economy model and suggest that these aspects of the growth in government have eroded trust in government. We find no evidence of positive associations between trust and government size and trust and lobbying, as might be expected from a public interest view of government.

While seemingly paradoxical, the negative association between growth of government and trust in government is consistent with a political economy/rent-seeking view of government growth and also is broadly consistent with the sweep of historical data since the late 1950s. With the more econometrically sophisticated examination of the data reported in this paper, we find this view is confirmed with respect to two measures of government, though not with respect to others. 


\section{References}

Alesina, Alberto and Warcziarg, Romain. (2000). “The Economics of Civic Trust.” In Disaffected Democracies: What's Troubling the Trilateral Countries, Susan J. Pharr and Robert D. Putnam, (eds.). Princeton, NJ: Princeton University Press.

Baumol, W. J. (1967). “The Microeconomics of Unbalanced Growth: The Anatomy of Urban Crisis.” American Economic Review, 57 (3), pp. 415-26.

Becker, G. S., (1983). “A Theory of Competition Among Pressure Groups for Political Influence.” Quarterly Journal of Economics, 98 (3), pp. 371-400.

Berggren, Niclas and Christian Bjørnskov. (Forthcoming). "The Market-Promoting and MarketPreserving Role of Social Trust in Reforms of Policies and Institutions,” Southern Economic Journal.

Berggren, Niclas, Christian Bjørnskov, and David Lipka. (2015). "Legitimacy and the Cost of Government.” Public Choice, 162(3-4), pp. 307-28.

Blendon, Robert, John Benson, Richard Marin, et al. (1997). "Changing Attitudes in America." In Why People Don't Trust Government, Joseph S. Nye Jr., Philip D. Zelikow, and David C. King, (eds). Cambridge, MA: Harvard University Press, pp. 205-16.

Blind, Peri K.. (2006). "Building Trust in Government in the Twenty-First Century: Review of Literature and Emerging Issues,” UNDESA.

Borcherding, Thomas and Dong Lee. (2004) “The Growth of the Relative Size of Government.” In Charles Rowley and Friedrich Schneider (eds.), The Encyclopedia of Public Choice. Kluwer Academic Publisher: New York, pp. 597-602.

Brennan, G. and Buchanan, J. M. (1977). “Towards a Tax Constitution for Leviathan.” Journal of Public Economics, 8, pp. 255-74.

Dalton, Russell. (2004). Democratic Challenges, Democratic Choices: The Erosion of Political Support in Advanced Industrial Democracies. Oxford, UK: Oxford University Press.

Dawson, John W. and John J. Seater, (2013). "Federal Regulation and Aggregate Economic Growth.” Journal of Economic Growth, 18 (2), pp. 137-77.

Demsetz, H. (1982). “The Growth of Government,” in deVries Lectures, no. 4. Economic, Legal and Political Dimensions of Competition. Amsterdam: North-Holland.

Fehr, Ernst and Simon Gachter. (2000). "Fairness and Retaliation: The Economics of Reciprocity,” Journal of Economic Perspectives, 14(3), pp. 159-81. 
Ferris, J.S. and West, E.G. (1993). "Changes in the Real Size of Government: US Experience 1948-1989.” Carleton Economic Papers 93-0, Department of Economics, Carleton University.

Ferris, J.S. and West, E.G. (1999). “The Cost Disease versus Leviathan Explanations of Rising Government Cost.” Public Choice, 98, pp. 307-16.

Fukuyama, Francis. (2000). “Social Capital and Civil Society,” IMF working paper.

Garen, John and Clark, J.R. (2015). “Trust and the Growth of Government.” Cato Journal, 35(3), pp. 549-80.

Gemmell, N., (1990). “Wagner's Law, Relative Prices and the Size of the Public Sector,” The Manchester School, 57, pp. 361-77.

Gramlich, E.M. (1985). “Excessive Government Spending in the U.S.: Facts and Theories.” in E. M. Gramlich and B. C. Ysander (eds.), Control of Local Government. Stockholm: Almqvist and Wiksell International, pp. 29-73.

Hayashi, N., Ostrom, E., Walker, J., and Yamagishi, T. (1999). "Reciprocity, Trust, and the Sense of Control: A Cross-Societal Study.” Rationality and Society 11 (1): 27-46.

Henrekson, M. (1990). An Economic Analysis of Swedish Government Expenditure, Ph.D. Thesis, Gothenburg University.

Henrich, J.; Boyd, R.; Bowles, S.; Camerer, C.; Fehr, E.; Gintis, H.; and McElreath, R. (2001). "In Search of Homo Economicus: Behavioral Experiments in 15 Small-Scale Societies." American Economic Review 91 (2): 73-8.

Hetherington, Marc, (2005). Why Trust Matters: Declining Political Trust and the Demise of American Liberalism, Princeton, NJ: Princeton University Press.

Holsey, C.M. and Borcherding, T.E. (1997). "Why Does Government’s Share of National Income Grow? An Assessment of the Recent Literature on the U.S. Experience.” In D.C. Mueller (ed.), Perspectives on Public Choice: A Handbook, New York: Cambridge University Press, pp. 562-589.

Hunter, James D. and Carl D. Bowman. (1996). The State of Disunion: 1996 Survey of American Political Culture Vol. 1. Summary Report. Charlottesville, VA: The Post-Modernity Project, University of Virginia.

Husted, T., and Kenny, L. (1997). “The Effect of the Expansion of the Voting Franchise on the Size of Government.” Journal of Political Economy, 105, 1997, pp. 54-82.

Johansen, Soren. (1991). "Estimation and Hypothesis Testing of Cointegration Vectors in Gaussian Vector Autoregressive Models.” Econometrica, 59 (6), 1551-80. 
Kau, James and Paul Rubin. (2002). “The Growth of Government: Sources and Limits.” Public Choice, 113 (3/4), pp. 389-402.

Knack, Stephen and Philip Keefer. (1997). “Does Social Capital Have an Economic Payoff? A Cross-Country Analysis.” Quarterly Journal of Economics 112(4): 1251-1288.

Levi, Margaret; Tyler, Tom; and Sacks, Audrey. (2008). “The Reasons for Compliance with Law.” Paper for Workshop on the Rule of Law, Yale University.

Lewis, M. (2010) “Beware of Greeks Bearing Bonds.” Vanity Fair (October), www.vanityfair.com/news/2010/10/greeks-bearing-bonds-201010.

Lott, T. and Kenny, L. (1998). “How Dramatically Did Women’s Suffrage Change the Size and Scope of Government?” Journal of Political Economy, 107, pp. 1163-98.

Lybeck, J.A. and Henrekson, M. (1988). Explaining the Growth of Government. Amsterdam: Elsevier Science Publishers.

Meltzer, A.H. and Richard, S.F. (1983). "Tests of a Rational Theory of the Size of Government." Public Choice, 41(3), pp. 403-18.

Mueller, D. C. (2004). “Public Choice: An Introduction.” In The Encyclopedia of Public Choice, Springer, pp. 32-48.

Nadler, Janice. (2005). “Flouting the Law.” Texas Law Review, 83: 1399.

Niskanen, W. A., (1971). Bureaucracy and Representative Government. Chicago: AldineAtherton.

Nye, Joseph S., Jr., Philip D. Zelikow, and David C. King, eds. (1997). Why People Don't Trust Government. Cambridge, MA: Harvard University Press.

Peltzman, S. (1980). “The Growth of Government.” Journal of Law and Economics, 27(2), pp. 209-87.

Perkins, G.M. (1977). “The Demand for Local Public Goods: Elasticities of Demand for Own Price, Cross Price and Income.” National Tax Journal, 30, pp. 411-22.

Pew Research Center for the People \& the Press. (2010). "The People and Their Government: Distrust, Discontent, Anger and Partisan Rancor.” Washington, D.C., http://peoplepress.org/reports/pdf/606.pdf.

Pharr, Susan J. (2010). “Officials’ Misconduct and Public Distrust: Japan and the Trilateral Democracies.” In Pharr, Susan J. and Putnam, Robert D. (eds.), Disaffected Democracies: What's Troubling the Trilateral Countries, Princeton, NJ: Princeton University Press. 
Ram, R. (1987). "Wagner's Hypothesis in Time-Series and Cross-Section Perspectives:

Evidence from 'Real Data' for 115 Countries.” Review of Economics and Statistics, 69, pp. 194-204.

Sobel, Russell S., and J. R. Clark. (In preparation). "Does More Special Interest Group Activity Cause Government Growth or Does Government Growth Cause More Special Interest Group Activity?” Cato Journal.

Sobel, Russell S. and Thomas A. Garrett. (2002). "On the Measurement of Rent Seeking and Its Social Opportunity Cost.” Public Choice, 112 (1-2), 115-36.

Spann, R. M. (1977). "Rates of Productivity Change and the Growth of State and Local Governments.” In T. E. Borcherding (ed.), Budgets and Bureaucrats: The Sources of Government Growth, Durham, NC: Duke University Press, pp. 102-129.

Stigler, G. J. (1970). “Director’s Law of Public Income Distribution,” Journal of Law and Economics, 13(1), pp. 1-10.

Tarabar, Danko and Joshua Hall. (2015). "The Seventeenth Amendment, Senate Ideology, and the Growth of Government: An Empirical Note.” Applied Economics Letters, 22(8), pp. 637-640.

Wagner, A., (1893). Grundlegung der Politshen Oekonomie, 3rd edition. Leipzig.

Warren, Mark E. (ed.). (1999). Democracy and Trust, Cambridge, UK: Cambridge University Press. 


\section{Appendix}

This appendix outlines the synthesis of Garen and Clark (2015) that underlies equations (1) through (4).

For individuals or individual organizations, let the following definitions hold. $\mathrm{h}=$ effort in productive activity, e.g., hours of work $(1-\tau) \mathrm{w}=$ the after-tax return to productive activity, where $\tau$ is the tax rate $\mathrm{s}=$ effort in political support activity $r=$ the return to each unit of political support activity, assumed not to be subject to tax $\mathrm{t}=$ degree of trust in and cooperation with government $\mathrm{C}(\mathrm{h}, \mathrm{s})=$ the utility cost of effort. Assume that there is increasing marginal cost of each type of effort $\left(\mathrm{C}_{\mathrm{ii}}>0, \mathrm{i}=\mathrm{h}, \mathrm{s}\right)$ and $\mathrm{C}_{\mathrm{hs}}>0$

Let the individual's utility function be:

$$
\mathrm{U}=(1-\tau) \mathrm{wh}+\mathrm{rs}-\mathrm{C}(\mathrm{h}, \mathrm{s})+\beta \mathrm{t}-\varphi(\mathrm{t})
$$

The first two terms are the after-tax income from work and the payoff from political support effort, respectively. The third term is the utility cost of effort. The last two terms represent the individual's benefit and cost of trust in and cooperation with government.

The final two terms originate from the experimental and psychology literatures as discussed above and reviewed in Garen and Clark (2015). This literature implies that individuals gain utility from cooperation with persons that they judge as being worthy, and that this sentiment is applied to government. The final terms in the utility function (A1) reflect this.

This is incorporated into the model as follows: The marginal benefit of trust/cooperation is given by the parameter $\beta$, implying that better government generates higher values of $\beta$. Define $\mathrm{G}$ as government spending on the value-enhancing aspects of government; denote aggregate 
political support activity as S; and so rS is total government support of rent-seeking. Let $\beta=\mathrm{G} /(\mathrm{G}+\mathrm{rS})$ so that the marginal utility of cooperation with government rises with the share of $G$ in total spending and falls with rS. This captures the essence of the foregoing arguments that cooperation ensues from value-enhancing government, and the converse from government activity that generates political activities.

The individual chooses work effort (h), political support effort (s), and cooperativeness (t) to maximize utility. It is also assumed that each individual has an infinitesimal effect on economy-wide aggregates and so are taken as given. It is straightforward that political support effort (s) rises with $r$ and falls with $w$. This is true for the individual and in aggregate. With productivity (P) as a proxy for $\mathrm{w}$, and $\Omega_{1}$ representing r, this yields equation (1) in the text, where $\mathrm{S}$ rises with $\Omega_{1}$ and falls with $\mathrm{P}$. This also implies text equation (2), where total rentseeking government support rises with $\Omega_{1}$ and falls with $\mathrm{P}$.

From the utility maximizing choice of $t$ based on (A1), it is straightforward that individual and aggregate trust fall with aggregate government support of rent-seeking relative to G. With R representing government support of rent-seeking, this is expressed in text equation (3) where $\mathrm{T}$ is a declining function of $\mathrm{R}$.

Finally, recall from the foregoing discussion that functions of government such as establishing and enforcing property rights, maintaining good contract law, promoting competition, and dealing with public goods and externalities raises productivity. Also from the foregoing, the literature indicates that citizen cooperation with government enhances these productivity-augmenting effects. This is expressed in the following way: Denote the aggregate level of trust of and cooperation with the government by $\mathrm{T}$, then:

(A2) $\mathrm{w}=\mathrm{w}(\mathrm{G}, \mathrm{T})$, with $\mathrm{w}_{\mathrm{G}}>0, \mathrm{w}_{\mathrm{T}}>0$, and $\mathrm{w}_{\mathrm{GT}}>0$ 
Again, with $\mathrm{P}$ as a proxy for $\mathrm{w}$, this implies that productivity rises with $\mathrm{T}$ and falls with rentseeking government, R. This is as expressed in equation (4). Thus, each of equations (1) through (4) are consistent with the Garen and Clark (2015) synthesis. 